University of Nebraska - Lincoln

DigitalCommons@University of Nebraska - Lincoln

1964

\title{
Effect on Residual and Contact Sprays On the Resistance of the German Cockroach to Chlordane
}

\author{
G. S. Burden \\ USDA \\ C. S. Lofgren \\ USDA \\ J. B. Gahan \\ USDA
}

Follow this and additional works at: https://digitalcommons.unl.edu/entomologyother

Part of the Entomology Commons

Burden, G. S.; Lofgren, C. S.; and Gahan, J. B., "Effect on Residual and Contact Sprays On the Resistance of the German Cockroach to Chlordane" (1964). Entomology Papers from Other Sources. 20.

https://digitalcommons.unl.edu/entomologyother/20

This Article is brought to you for free and open access by the Entomology Collections, Miscellaneous at DigitalCommons@University of Nebraska - Lincoln. It has been accepted for inclusion in Entomology Papers from Other Sources by an authorized administrator of DigitalCommons@University of Nebraska - Lincoln. 


\title{
EFFECT OF RESIDUAL AND CONTACT SPRAYS ON THE RESISTANCE OF THE GERMAN COCKROACH TO CHLORDANE
}

\begin{abstract}
G. S. Burden, C. S. Lofgren, ANd J. B. Gahan
Entomology Research Division, Agric. Res. Serv., USDA, Gainesville, Fla.

When contact sprays are applied for cockroach control, they are dispersed with the expectation that they will kill the insects actually in the room at that time but will have little if any effect on those that enter after the spraying has been completed. Residual sprays, which are applied to stationary objects such as walls or furniture, have the added advantage of also being toxic to those cockroaches that contact the treated surfaces at a later date. If the residual treatments actually kill a greater number of insects, they also may select for resistance at a much higher level and cause such resistance to develop more rapidly. In an effort to determine whether residual sprays produce resistant strains more readily than space sprays, or vice versa, a series of tests was conducted under simulated natural conditions in which German cockroaches, Blattella germanica (L.), were exposed to chlordane treatments.
\end{abstract}

\section{Procedures}

To establish the test environments, four large rooms were sealed to retain the test insects. Two of these large rooms were partitioned to make two smaller test rooms, each with an adjoining reservoir or colony room. Small openings were cut in each partition to allow movement of cockroaches between the test and reservoir rooms. Harborages were attached to the walls in each room, and food and water were placed in the center area of the floor. Each room was infested with approximately 300 German cockroaches from the NPCA colony. This colony originally possessed resistance to the chlorinated hydrocarbon insecticides (Stitt 1955; Keller et al. 1956) but has been maintained in the laboratory for numerous generations without exposure to insecticides and thus has lost most of its resistance. It was used because of the desirability of working with a cockroach strain known to possess the genetic characteristics for resistance.

After allowing about a month for the cockroaches to adjust to the rooms, strips approximately 3 feet wide along the baseboards and around the feeding area in one of the large rooms and one of the smaller partitioned rooms were treated with a residual spray containing $2.0 \%$ of chlordane in oil. In addition, approximately $75 \%$ of the cockroaches in one of the large rooms and one of the smaller partitioned rooms were treated with a contact spray containing $2.0 \%$ of chlordane in oil. Both treatments were repeated at 6 -week intervals. The reservoir rooms were not treated.

At intervals of $3,4 \frac{1}{2}$, and 6 months after the start of the experiment, male cockroaches were collected from each room and exposed continuously to $10 \mathrm{mg}$. of chlordane per square foot in pint glass jars by the test method described by Keller et al. (1956). The LT-50's were computed from the length of time required to knock down or kill $50 \%$ of the cockroaches. The amounts of resistance developed based on the ratios of the LT-50's of the treated collections to the LT-50 of the parent colony, are shown in Table 1. 
TABLE 1.-Resistance to Chlordane Developed by Strains of The German Cockroach Subjected to Different Treated Environments.

\begin{tabular}{|c|c|c|c|c|}
\hline \multirow{2}{*}{$\begin{array}{l}\text { Strain } \\
\text { number }\end{array}$} & \multirow[b]{2}{*}{ Treatment } & \multicolumn{3}{|c|}{$\begin{array}{c}\text { Ratio of } \mathrm{LT}-50 \text { to that of } \\
\text { parents after indicated } \\
\text { months* }\end{array}$} \\
\hline & & 3 & $4 \frac{1}{2}$ & 6 \\
\hline $1 \mathrm{~A}$ & Residue in partitioned room & 1.3 & 4.2 & 8.3 \\
\hline $1 \mathrm{~B}$ & Reservoir for partitioned residue room & 1.8 & 1.1 & 7.7 \\
\hline $2 \mathrm{~A}$ & Contact spray in partitioned room & 3.5 & 2.2 & 6.9 \\
\hline $2 \mathrm{~B}$ & $\begin{array}{l}\text { Reservoir for partitioned contact- } \\
\text { spray room }\end{array}$ & 3.0 & 1.7 & 3.6 \\
\hline 3 & Residue in unpartitioned room & 8.0 & 5.9 & 12.7 \\
\hline 4 & Contact spray in unpartitioned room & 4.3 & 7.7 & 9.0 \\
\hline
\end{tabular}

* LT-50's of parent colony were as follows: initial, 4.7 hours; 3 months, 4.7 hours ; 41/2 months, 4.5 hours; 6 months, 5.3 hours. Each LT-50 represents the average of two tests of ten adult males each.

\section{RESUlts}

Of the cockroaches confined in rooms without reservoirs, the group exposed to the residue treatment (strain number 3) was more tolerant to chlordane than the group exposed to contact sprays (strain number 4) at the third and sixth months after the initial treatments; however, the tolerances were slightly reversed after $4 \frac{1}{2}$ months.

Results of tests with cockroaches collected from the treated rooms with reservoirs indicated that during the first 3 months the contact sprays had a greater effect on resistance than the residual sprays, but the reverse was evident after $4 \frac{1}{2}$ to 6 months.

\section{Discussion}

The degree of exposure appeared to be the principal factor that affected the rate at which resistance developed, since all strains developed some measurable resistance to chlordane within 3 months and showed further increases at 6 months. However, the resistance developed most rapidly and became highest with those cockroaches forced to stay continuously in the treated rooms, regardless of the type of treatment applied. Similarly, during two of the three testing periods, the insects exposed to the residual sprays showed more resistance than those exposed to contact sprays in both types of treated rooms.

There was some movement of cockroaches to and from the treated and reservoir rooms, since resistant insects were present in both places. However, this movement appeared to be limited because the resistance was usually higher in cockroaches in the treated room than in those in the untreated room. This is a normal expectation and could occur in wild populations subjected to insecticides during a control program. 


\section{SUMMARY}

When German cockroaches (Blattella germanica (L.)) were confined to environments treated with chlordane, susceptibility tests indicated that strains subjected to residual sprays developed resistance at a slightly greater rate and degree than those subjected to contact sprays. The degree of exposure appeared to be the principal factor that affected the rate at which resistance developed, since all strains developed some measurable resistance to chlordane within 3 months and showed further increases at 6 months.

\section{Literature Cited}

Keller, J. C., P. H. Clark, C. S. Lofgren, and H. G. Wilson. 1956. Results of USDA-sponsored research tests on cockroach control. Pest Control 24(9): 12, 14, 17, 19-20.

Stitt, L. L. 1955. Chlordane resistant roach studies. Pest Control 23 (11): 23 .

\section{BOoK NoTE}

To Know A Fly. V. G. Dethier. Holden-Day, Inc., San Francisco, 1962. 119 p. illus. $\$ 3.75$.

To Know A Fly was written for non-scientists, lay-scientist, and scientist alike. It is clearly written in terms a non-scientist can understand. In this respect Dethier contributes to bridging the gap between C. P. Snow's two cultures.

Undoubtedly this book holds most pleasure for the scientist, many of whom will experience a measure of vicarious pleasure from Dethier's experimental accounts.

The book starts out on a light note and becomes progressively lighter until it reaches a climax in the final chapter where an about face is made with the drama ending in a serious note. In the last chapter Dethier gives the scientist's raison d' etre. In doing this he justifies his lifelong workand that of others like him-in striving "To Know A Fly".

The book abounds with anectdotes, answers to thought-provoking questions, and definitions. Questions such as how a fly lands on the ceiling, how to get an air-conditioned laboratory, and how to obtain a "clutch" of black blow fly eggs are unequivocally answered. Definitions are just as far ranging, e.g., graduate student is "an overworked and underpaid sheep in the academic wilderness", and trail is "a series of signs or continuous signs".

Bill Clark's drawings are a bonus feature; they are tailor-made to illustrate (or over-illustrate) points made in the text.

To Know A Fly is a brilliant tour de force which is at once humorous, didactic, and inspiring. Throughout Dethier writes with such verve about the work with which he has been engaged for nearly two decades that the book is impossible to read without having some of his enthusiasm rub off.

It most certainly is required reading for all scientists who need not only a treat but also a treatment. It is recommended reading for the nonscientist who wants to find out what (some) biologists are doing and what causes them to tick.-G. M. STOKES. 